\title{
PERANAN PANCASILA TERHADAP SISTEM KETATANEGARAAN REPUBLIK INDONESIA BERDASARKAN PERSPEKTIF HUKUM DI MASA KINI
}

\author{
Rizky Handayani ${ }^{1)}$, Nurul Ai'ni' ${ }^{2)}$, Anita Trisiana ${ }^{3)}$ \\ ${ }^{1)}$ Mahasiswa Pertanian Universitas Slamet Riyadi Surakarta \\ ${ }^{2)}$ Mahasiswa Pertanian Universitas Slamet Riyadi Surakarta \\ ${ }^{3)}$ Dosen Pendidikan Pancasila Universitas Slamet Riyadi Surakarta
}

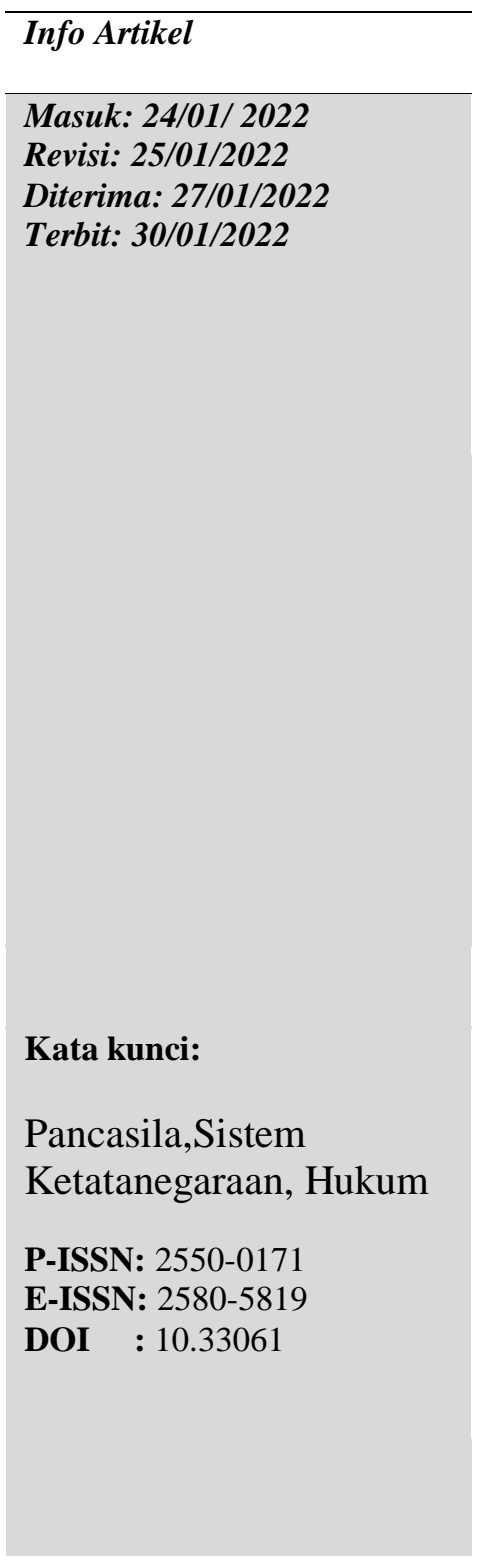

\begin{abstract}
This writing aims to find out how the role of the Pancasila in the implementation of the constitutional system of the Republic of Indonesia according to a law perspective in the present era. This data is taken by using descriptive analytical methods namely by analyzing how the role of the Pancasila in the state administration system in Indonesia by considering the law in the present. Pancasila as the ideology of the nation has a role in daily life, especially in the implementation of this nation's constitutional system. Law is also involved play a critical role in in this system. However, the application of Pancasila values in the state administration has started to faded away. In the practice of law also begin to form of deception. Law should be used as a guideline in the implementation, but now it seems as if it has lost to the culture of the times. So it needs the evaluation that the application in accordance with the values of Pancasila from the perspective of law.
\end{abstract}

\section{Abstrak}

Penulisan ini bertujuan untuk mengetahui bagaimana peranan Pancasila dalam pelaksanaan sistem ketatanegaraan Republik Indonesia menurut perspektif hukum di era ini. Data ini diambil dengan menggunakan metode deskriptif analitik yakni dengan menganalisis bagaimana peranan Pancasila terhadap sistem tata negara di Indonesia dengan mempertimbangkan hukum di masa kini. Pancasila sebagai ideologi bangsa memiliki peranan dalam kehidupan seharihari, terutama pada pelaksanaan sistem ketatanegaraan bangsa ini. Hukum juga ikut berperan penting dalam sistem ini. Namun, penerapan nilai-nilai Pancasila dalam 
ketatanegaraan mulai luntur. Dalam praktek hukum juga mulai terbentuk penyimpangan. Seharusnya, hukum dijadikan pedoman dalam pelaksanaannya namun sekarang seakanakan sudah kalah dengan budaya perkembangan zaman. Sehingga perlu adanya evaluasi agar penerapannya sesuai dengan sila-sila Pancasila menurut perspektif hukum.

\section{PENDAHULUAN}

Pancasila merupakan ideologi bangsa Indonesia. Pancasila merupakan sutu asas, kesatuan, persatuan, kerjasama, damai, dari bangsa Indonesia yang penduduknya mempunyai kesamaan dan perbedaan. Dalam kehidupan sehari-hari Pancasila memiliki peranan penting dalam berjalannya sistem ketatanegaraan. Dari masa proklamasi sampai masa reformasi tentu banyak terjadi pergantian sistem, peraturan dan hukum yang menjadi pedoman berjalannya pemerintahan di Indonesia.

Faktanya hukum sangatlah mendasari tata cara pelaksanaan sistem ketatanegaraan karena Indonesia adalah negara hukum. Namun saat ini hukum sudah berkurang ketaatannya sehingga banyak sekali penyimpanganpenyimpangan yang menimbulkan tenggelamnya kehidupan berbangsa dan bernegara sesuai dengan konsep ideologi Pancasila. Perjalanan sejarah menunjukkan kedudukan Pancasila sebagai dasar negara dan ideologi mengalami pasang surut atau kemunduran. Setelah runtuhnya masa orde baru, Pancasila sedikit demi sedikit mulai tenggelam begitu juga hukum dalam lingkaran history. Pancasila semakin jarang diucapkan, diterapkan, dan digunakan baik dalam tatanan kehidupan ketatanegaraan, kebangsaan, maupun kemasyarakatan. Bahkan banyak kalangan mengungkapkan bahwa sebagian masyarakat Indonesia nyaris melupakan jati dirinya yang hakikatnya adalah Pancasila. Pancasila tampak semakin terpinggirkan dari kehidupan bangsa Indonesia dan sebagai dasar negara kini nyaris kehilangan fungsinya, seolah hanya tinggal simbolisnya saja. 
Yang penulis maksudkan dengan tinjuan ini adalah untuk mengetahui bagaimana peranan nilai-nilai Pancasila terhadap sistem ketatanegaraan Republik Indonesia berdasarkan perspektif hukum di masa kini. Sehingga dengan menganalisisnya kita dapat mengetahui bagaimana langkah kita dalam menyikapi masalah-masalah yang menyangkut sistem ketatanegaraan dimana sudah terlalu jauh dari pedoman hukum yang ada.

\section{METODE}

Metode yang dipakai dalam pembuatan pembahasan ini ialah metode deskriptif analitik. Adapun pengertian dari metode deskriptif analitik menurut Sugiono (2009:29) adalah "Metode deskriptif merupakan suatu metode yang berfungsi untuk mendeskripsikan atau memberi gambaran terhadap objek yang diteliti melalui data atau sampel yang telah terkumpul sebagaimana adanya tanpa melakukan analisis dan membuat kesimpulan yang berlaku untuk umum. Penelitian tersebut bertujuan untuk memperoleh pemaparan yang objektif mengenai analisis bagaimana peranan Pancasila dalam berjalannya sistem ketatanegaraan Republik Indonesia yang dipadukan dengan unsur-unsur hukum dimasa sekarang.

\section{PEMBAHASAN}

Dewasa ini kita telah menemukan berbagai macam perubahan sistem ketatanegaraan yang diberlakukan di negara ini. Dari zaman proklamasi sampai masa reformasi tentu banyak perubahan yang terjadi. Faktor yang menyebabkan sering terjadinya perubahan sistem ini adalah dengan adanya kultur adat istiadat yang juga ikut berubah seiring perkembangan zaman. Dalam nilai-nilai Pancasila tentunya sistem ini sudah ditata agar sesuai dengan cita-cita bangsa ini. Peranan Pancasila sebetulnya harus dipegang begitu erat agar tidak melenceng jauh dari pedoman yang ada.

Pancasila yang berkaitan dengan hukum selalu memiliki kecenderungan bahwa Pancasila ditempatkan pada posisi tertinggi dalam tatanan hukum Indonesia. Hal ini dijelaskan oleh Shidarta bahwa Pancasila menjadi suatu pemandu atau litstern, 
yang berisi materi dan kerangka hukum, serta lingkungan kehidupannya adalah budaya hukum (Susanto, A. 2010:294)

Pada faktanya hukum yang mengatur tata negara yang berlaku saat ini sudah mulai berkurang kualitasnya. Bahwa hukum tata negara ada untuk mempermudah penyelenggaraan kedaulatan rakyat di negara ini. Dapat dikatakan bahwa segala hukum merupakan hukum tata negara. Lantas, ketika hendak menyusun hukum tersebut tentunya kita membutuhkan suatu dasar yang akan memandu penyusunan tata negara. Panduan tersebut ialah asas hukum tata negara yang harus ditaati.

Logemann mengatakan bahwa hukum tata negara mempelajari:

a. Siapa yang mengadakan jabatan itu;

b. Jabatan-jabatan yang ada dalam susunan suatu Negara;

c. Fungsi/lapangan kerja jabatan-jabatan tersebut;

d. Cara bagaimana jabatan-jabatan tersebut ditempatkan oleh pejabat;

e. Kekuasaan hukum jabatan-jabatan tersebut;

f. Batas alat-alat kenegaraan dapat melaksanakan tugasnya;

g. Hubungan masing-masing jabatan.

Istilah Negara Hukum dalam ilmu ketatanegaraan telah lama dikenal yakni sejak zaman prasejarah hingga zaman modern. Namun dalam prakteknya masih banyak yang mengasingkan bahwa negara hukum tersebut telah terlaksana sepenuhnya. Apabila kondisi ini terjadi secara terus-menerus maka negara hukum yang dicita-citakan tersebut akan bersifat simbolis saja, sehingga istilah tata negara hanya dimaknai sebagai simbol atau mitos semata yang tidak pernah terbukti dalam implementasi sepanjang sejarah kehidupan ketatanegaraan.

Hukum yang ditegakkan dalam negara hukum adalah hukum yang akan membawa kebenaran untuk menunjukkan rasa keadilan. Jadi hukum di dalam negara hukum harus tumbuh dan ditentukan secara demokratis, sumber kedaulatan rakyat melalui cara-cara yang demokratis, dan pelaksanaannya berada dibawah kontrol dan menurut tata cara konstitusional tertentu di dalam tiap-tiap negara bersangkutan. 
Jadi setiap individu sudah seharusnya menanamkan ketaatan hukum tersebut sejak dini di dalam diri. Ketika kesadaran akan taat hukum itu ada, maka sistem itu pasti akan berjalan sesuai dengan hukum dan Pancasila mulai dari tatanan yang paling rendah yakni keluarga sampai yang paling tinggi yaitu tata pemerintahan.

Sebenarnya peranan Pancasila ialah sebagai pedoman pelaksanaan terhadap sistem ketatanegaraa yang juga didasari hukum yang telah ditentukan. Namun pada faktanya seperti pembahasan diatas bahwa banyak sekali penyimpanganpenyimpangan terhadap sistem ini. Seperti yang dilihat dalam perlakuan seharihari, banyak penguasa negara maupun warga negara yang menyalahgunakan kekuasaan untuk keperluan mereka masing-masing.

\section{PENUTUP}

Peranan Pancasila sebagai ideologi bangsa yang menjadi pedoman pelaksanaan sistem ketatanegaraan di Indonesia pada dasarnya sangatlah penting. Pancasila menjadi poin penting sehingga sistem ini sudah diatur dengan baik. Selain ideologi tentunya ada hukum-hukum yang juga turut mengatur berjalannya tata negara. Namun dalam pelaksanaan hukum sudah mulai berkurang ketaatannya di muka umum. Seolah-olah mulai tenggelam eksistensinya dan mulai larut dengan perkembangan zaman serta kalah dengan teknologi yang berlaku saat ini.

Fenomena yang terjadi saat ini adalah banyaknya sikap individualisme dan egoisme yang menempel dalam individu masing-masing. Padahal dalam implementasinya harus saling bekerja sama, bermusyawarah untuk mencapai mufakat, sehingga akan berkurang rasa individualis dan egoisme.

\section{DAFTAR PUSTAKA}


Ayu, Felisia Mega Sri, dan Trisiana, Anita. 2017. Penguatan Pancasila Dalam Perbuatan (Alternatif Tindakan Kuratif Di Era Globalisasi). Jurnal Global Citizen, Vol. 4 No. 2, Pp. 14-19

Kansil. 1986. Hukum Antar Tata Pemerintahan. Jakarta: Erlangga.

Notonagoro. 1971. Pancasila Secara Ilmiah Populer. Yogyakarta: Bina Aksara.

Parthiana, I Wayan. 2009. Ekstradisi Dalam Hukum Internasional Modern. Bandung: Yrama Widya.

Purwadi, H., Firdausy, Adriana G. 2015. Konsekuensi Tranplantasi Hukum Terhadap Pancasila Sebagai Norma Dasar Dan Hukum Lokal. Vol. 4 No. 1 Pp. $73-88$

Rahayu, Derita Prapti. 2015. Aktualisasi Pancasila Sebagai Landasan Hukum Indonesia. Yustisia, Vol.4 No.1

Sailan, Manan. 2011. Istilah Negara Hukum Dalam Sistem Ketatanegaraan Republik Indonesia. Mmh, Jilid 40 No.2, Pp 228-234

Sunoto. 1987. Mengenal Filsafat Pancasila. Yogyakarta: PT. Hanindita Graha Widya.

Taopan, M. 1992. Keunggulan Pancasila Sebagai Filsafat Kenegaraan. Bandung: PT. Citra Aditya Bakti.

Widisuseno, Iriyanto. 2014. Azas Filosofis Pancasila Sebagai Ideologi Dan Dasar Negara. Humanika Vol. 20 No. 02 Pp 62-66. 